\title{
Effect of Cow Colostrum, Mare Milk, and Human Milk on the Viability of Lung Healthy and Cancer Cell Lines
}

\author{
Ertugrul Osman Bursalioglu1,* (iD) \\ ${ }^{1}$ Vocational School of Health Services, Sinop University, Sinop, Turkey \\ * Corresponding author: Ertugrul Osman Bursalioglu, Vocational School of Health Services, Sinop University, Sinop, Turkey. Tel: \\ +9039682715758; Email: ebursalioglu@sinop.edu.tr
}

Received 2021 February 01; Revised 2021 February 26; Accepted 2021 April 17.

\begin{abstract}
This study investigated the effects of lyophilized mare milk, human milk, and cow colostrum on both human lung cancer cell line called A549, and healthy lung cell line called MRC5. Mare milk, human milk, and cow colostrum varieties were applied to 6 replicates in both cell lines with lyophilized milk concentrations ranging from $50-3200 \mathrm{ppm}$. The cell viability was monitored by optic microscopy and determined by the MTT test. ANOVA and Duncan's multiple range tests were used to analyze data. The results of this study indicated that the most effective milk type on reducing the A549 lung cancer cell line was human milk, followed by mare milk; however, cow colostrum showed little effect. It was observed that human milk and mare milk had anti-proliferative effects on lung cancer cell line at concentrations which were non-toxic to healthy lung cell line.

Keywords: Cell viability, Colostrum, Cow milk, Human milk, Mare milk
\end{abstract}

\section{Background}

Milk and dairy products from animals can be used in the treatment of cancer and various diseases. Cancer is the most common risk that threatens human health worldwide, and a total annual economic cost is approximately US\$ 1.16 trillion $(1,2)$. Lung cancer is the leading cause of cancerrelated deaths worldwide (3), accounting for about 2 million deaths per year (4).

Milk is a highly nutritious food for both children and adults since it is a source of high-quality proteins, vitamins, and minerals. Milk proteins are good sources of bioactive peptides that provide a variety of biological activities including antioxidant, immunemodulating, cholesterol-lowering, anti-hypertension, anti-microbial, and anti-cancer (5-7). With these unique properties, milk originated from different mammals is being used in cancer studies $(6,8,9)$.

Human breast milk contains a variety of bioactive agents that modify the immune system function, gastrointestinal tract, and neuronal development (10). The results of an increasing number of studies have indicated that human milk offers protection against breast cancer, ovarian cancer, type II diabetes, obesity, and rheumatoid arthritis (11-13). Colostrum is known as a nutrient-packed fluid produced by the mammary glands in the last period of pregnancy just before birth. It contains developmental, immune, and tissue repair factors $(14,15)$. Lactoferrin (LF) protein, which is found in high amounts in the milk of mammals, has been shown that reduces non-small cell lung carcinoma (16). Akca et al. conducted a study on the effect of donkey milk on lung cancer lines (9). Koumiss is a traditional milk beverage and, - mildly alcoholic - , dairy-based drink that is sour-tasting produced from the fermentation of mares' milk $(17,18)$. Traditionally, it was produced from the milk of horses by residents in Central Asia and China, which is one of the most important basic food products (19). There has been an increasing interest in the production of koumiss at the industrial level due to its biotechnological potential and its benefits to human nutrition and health (20-22).

Considering the content of the milk from different sources and their activity in cancer, it is still highly demanded to investigate the effect of milk on different types of cancer. In this study, the cell viability of cow colostrum, mare milk, and human milk was evaluated on the viability of lung healthy and cancer cell lines. To this end, the human lung cancer cell line, called A549, - and a healthy lung cell line, called MRC5, were employed.

\section{Methods}

\subsection{Preparation of Milk Samples}

Cow colostrum, mare milk, and human milk were used for this study. Mare milk was obtained from Alas Mare Farm, - Izmir Kemalpasa, - Turkey. Cow colostrum and human milk were obtained from Sinop, - Turkey. The milk samples were kept at $110^{\circ} \mathrm{C}$ for $10 \mathrm{~min}$ and then stored at $-55^{\circ} \mathrm{C}$ in the freezer for $24 \mathrm{~h}$. The milk samples were lyophilized at $-80^{\circ} \mathrm{C}$ for 2 days before the cell viability tests. Hydrogen peroxide $\left(\mathrm{H}_{2} \mathrm{O}_{2}\right)$ was used as a positive control at a single concentration of $150 \mu \mathrm{M}$. Sterile distilled water 
was used in all experiments.

\subsection{Cell growth procedure}

Healthy human lung fibroblast (i.e., MRC5) and human lung cancer (i. e., A549) cell lines were provided from the American Type Culture Collection (Manassas, USA). The A549 lung cancer cells were cultured in F-12K medium supplemented with $10 \%$ fetal bovine serum (FBS), penicillin - potassium (50 $\mu \mathrm{g} / \mathrm{ml})$, streptomycin sulfate $(10,000 \mu \mathrm{g} \mathrm{mL}-1)$, amphotericin B (25 $\mu \mathrm{g} \mathrm{mL-1)}$, and 1\% L-glutamine. The MRC5 lung fibroblast cells were cultured in Eagle's minimal essential medium supplemented with $10 \%$ FBS, penicillin - potassium $(50 \mu \mathrm{g} / \mathrm{ml})$, streptomycin $(10,000 \mu \mathrm{g} \mathrm{mL}-1)$, amphotericin B (25 $\mu \mathrm{g} \mathrm{mL}-1)$, and $1 \%$ L-glutamine. Cells were grown and stocked until the cell density reached $80 \%$ in the incubator in 5\% $\mathrm{CO}_{2}$ and $90 \%$ humidity medium at $37^{\circ} \mathrm{C}$.

\subsection{Application of Lyophilized Milk Samples to Cell} Cultures and Determination of Cytotoxic Effects

When the cell density reached $85 \%$ in a flask, a 5$20 \times 10^{4}$ number was added in 96 -well plates and kept for 24-48 $\mathrm{h}$ to reach the appropriate density for cytotoxicity experiments. Later, lyophilized milk samples were applied to the cells in the concentration range of 3200-50 ppm. Pasteurized and lyophilized milk samples were treated with 7 different dose ranges using a negative control and a positive control group. For negative controls, the cells were kept in the growth medium. In positive controls, hydrogen peroxide $\left(\mathrm{H}_{2} \mathrm{O}_{2}\right)$ at $250 \mu \mathrm{M}$ concentration was applied to the cells. Cytotoxic effects were determined by the MTT method. That indicates the mitochondrial activity. For this purpose, $5 \mathrm{mg} / \mathrm{ml}$ of MTT in $100 \mu \mathrm{l}$ of growth medium was added to each well and incubated in an incubator at $37{ }^{\circ} \mathrm{C}$ for $4-12 \mathrm{~h}$. Then the top liquid in the wells was discarded and $150 \mu \mathrm{l}$ dimethyl sulfoxide was added to the wells to dissolve formazan crystals. To determine changes in cell proliferation, measurements were performed by using a microplate reader at $570 \mathrm{~nm}$.

The cell viability of each set was calculated according to the given formula:

$\%$ Cell Viability $=\frac{\text { Cell absorption with compound }- \text { Absorption of empty well }}{\text { Absorption of control cell }- \text { Absorption of empty well }} x 100$

Moreover, lyophilized milk samples were applied to the cells followed by being washed 3 times with phosphate-buffered saline before optic microscopy imaging.

\subsection{Statistical Analysis}

The data collected in this study were analyzed in SPSS software (version 15.1) using ANOVA and Duncan's multiple range tests for the numerical data obtained from the experiments.

\section{Results}

Mare milk, human milk, and cow colostrum samples were applied to the A549 lung cancer cell line and MRC5 healthy cell line. The cell viabilities of both A549 and MRC5 cell lines for different milk samples at different concentrations are summarized in Table 1.

Table 1 presents the effects of three types of milk namely, human, mare, and cow colostrum, in different concentrations on the A549 lung cancer cell line and MRC5 healthy lung cell lines. The mean and standard deviation scores and homogeneity groups (the codes used in Duncan's multiple range test) are tabulated in Table 1, which were acquired from 6 replicates in both cell lines.

For the case of mare milk, in both cell lines, dosedependent cytotoxicity was detected in a high concentration range (Figure 1). For all concentrations, MRC5 showed higher cell viability than A549. Even at $3,200 \mathrm{ppm}$, the cell viability values were still about $50 \%$.

The employment of cow colostrum resulted in around $20 \%$ in both A549 and MRC5 cell lines at

\begin{tabular}{|c|c|c|c|c|c|c|c|c|c|c|}
\hline \multirow{2}{*}{$\begin{array}{l}\text { Concentrations } \\
\text { (ppm) }\end{array}$} & \multirow{2}{*}{ Cell type } & \multicolumn{3}{|c|}{ Human Milk } & \multicolumn{3}{|c|}{ Mare Milk } & \multicolumn{3}{|c|}{ Cow colostrum } \\
\hline & & Mean & SD & HG & Mean & SD & HG & Mean & SD & HG \\
\hline \multirow{2}{*}{50} & A549 cancer lung cells & 0.40966 & 0.00079 & $\mathrm{GH}$ & 0.58466 & 0.029762 & LM & 0.612 & 0.0051215 & MN \\
\hline & MRC5 healthy lung cells & 1.29933 & 0.01700 & $\mathrm{Z}$ & 1.01933 & 0.0057726 & VW & 0.86966 & 0.0016127 & $\mathrm{U}$ \\
\hline \multirow{2}{*}{100} & A549 cancer lung cells & 0.38366 & 0.01905 & FG & 0.53666 & 0.060722 & $\mathrm{~K}$ & 0.58 & 0.020976 & LM \\
\hline & MRC5 healthy lung cells & 1.19833 & 0.00762 & $\mathrm{Y}$ & 0.826 & 0.0423509 & $\mathrm{~T}$ & 0.76266 & 0.003726 & $\mathrm{QR}$ \\
\hline \multirow{2}{*}{200} & A549 cancer lung cells & 0.35566 & 0.00854 & $\mathrm{~F}$ & 0.484 & 0.03234 & J & 0.591 & 0.0028284 & LM \\
\hline & MRC5 healthy lung cells & 1.14666 & 0.00310 & $X$ & 0.817 & 0.0124096 & ST & 0.73266 & 0.023390 & Q \\
\hline \multirow{2}{*}{400} & A549 cancer lung cells & 0.34933 & 0.01156 & $\mathrm{EF}$ & 0.459 & 0.025349 & IJ & 0.55666 & 0.0027283 & KL \\
\hline & MRC5 healthy lung cells & 1.05366 & 0.00610 & W & 0.78233 & 0.0624362 & RS & 0.639 & 0.0171230 & NO \\
\hline \multirow{2}{*}{800} & A549 cancer lung cells & 0.26566 & 0.01256 & $\mathrm{C}$ & 0.416 & 0.078153 & $\mathrm{GH}$ & 0.53666 & 0.003212 & $\mathrm{~K}$ \\
\hline & MRC5 healthy lung cells & 1.055 & 0.007 & $\mathrm{~W}$ & 0.733 & 0.0386626 & $\mathrm{Q}$ & 0.59466 & 0.0085128 & LM \\
\hline \multirow{2}{*}{1600} & A549 cancer lung cells & 0.25133 & 0.02178 & $\mathrm{C}$ & 0.43266 & 0.042603 & $\mathrm{HI}$ & 0.37033 & 0.001526 & $\mathrm{~F}$ \\
\hline & MRC5 healthy lung cells & 1.00833 & 0.00100 & V & 0.67933 & 0.0114486 & $\mathrm{P}$ & 0.538 & 0.0089218 & K \\
\hline \multirow{2}{*}{3200} & A549 cancer lung cells & 0.07933 & 0.00981 & A & 0.353 & 0.0492869 & $\mathrm{~F}$ & 0.173 & 0.0054037 & B \\
\hline & MRC5 healthy lung cells & 0.28333 & 0.01040 & $\mathrm{CD}$ & 0.65666 & 0.0092096 & $\mathrm{OP}$ & 0.314 & 0.0032863 & $\mathrm{DE}$ \\
\hline
\end{tabular}

Notes: SD: Standard deviation, HG: Homogeneity group: a section of experimental units comparable to each other in terms of a checked feature. Different letters in the columns show statistical differences, and the same letters in the columns represent that there is no statistical difference between samples according to Duncan's test of the multiplication range at 95\% confidence level in SPSS. While groups with more than one letter and with a common letter show no statistically significant difference, groups that lack a letter in common are statistically different. 


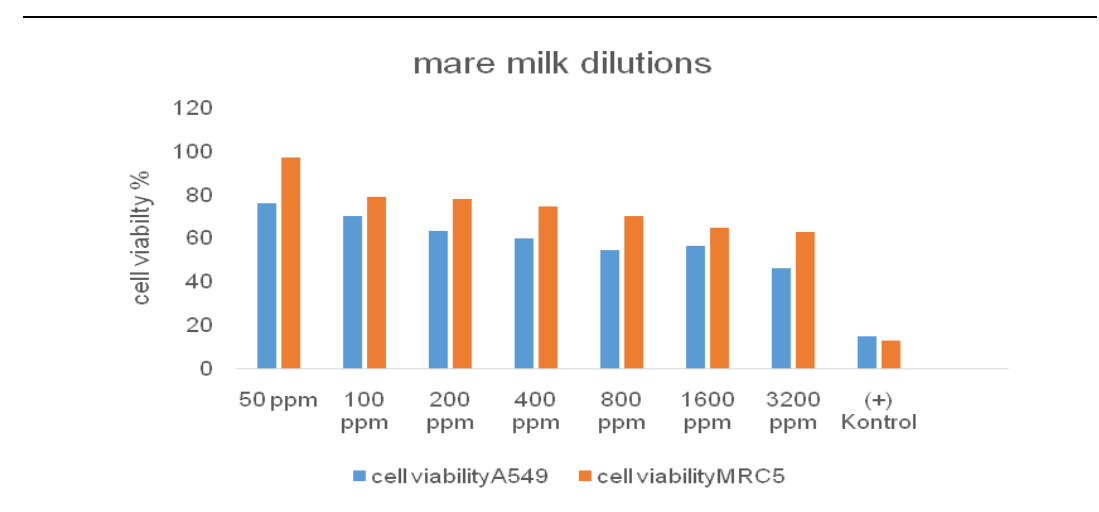
Figure 1. Effect of mare milk on cell viability of A549 and MRC5 cell lines at different
concentrations

3,200 ppm (Figure 2). Similar to mare milk, dosedependent cytotoxicity was observed in a high concentration range. In most cases, A549 cells showed higher viability than MRC5 cells.

The employment of human milk remarkably decreased the cell viability of A549 cell lines. However, the cytotoxicity in the MRC5 cell line was distinctively higher indicating the biocompatibility of human milk on this cell line. The cell viability started from around $120 \%$ and decreases to about $25 \%$. It is clear that the interaction of human milk with MRC5 cells significantly improved cell viability.

The objective images in figures $4 \mathrm{a}$ and $4 \mathrm{~b}$ are the microscope pictures of mare milk (shown in Figure 1 and Table1) applied to A549 cancer cells and MRC5 healthy cells at concentrations of 3,200 ppm and 50 ppm, respectively.

The objective image in Figure $5 \mathrm{a}$ is a microscope picture of the interaction of MRC5 healthy cells with the medium as a negative control. The microscopic picture in Figure $5 \mathrm{~b}$ is an image of human milk (shown in Figure 3 and Table1) applied to A549 cancer cells at a concentration of $1,600 \mathrm{ppm}$ to reduce cell viability.

The objective images in figures $6 \mathrm{a}$ and $6 \mathrm{~b}$ are the microscope pictures of human milk (shown in Figure 3

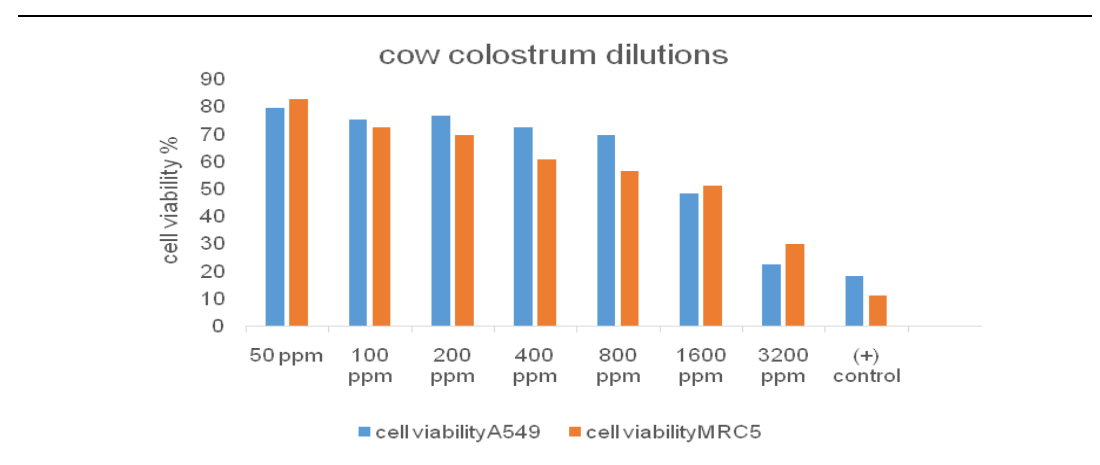

Figure 2. Effect of cow colostrum on cell viability of A549 and MRC5 cell lines at different concentrations

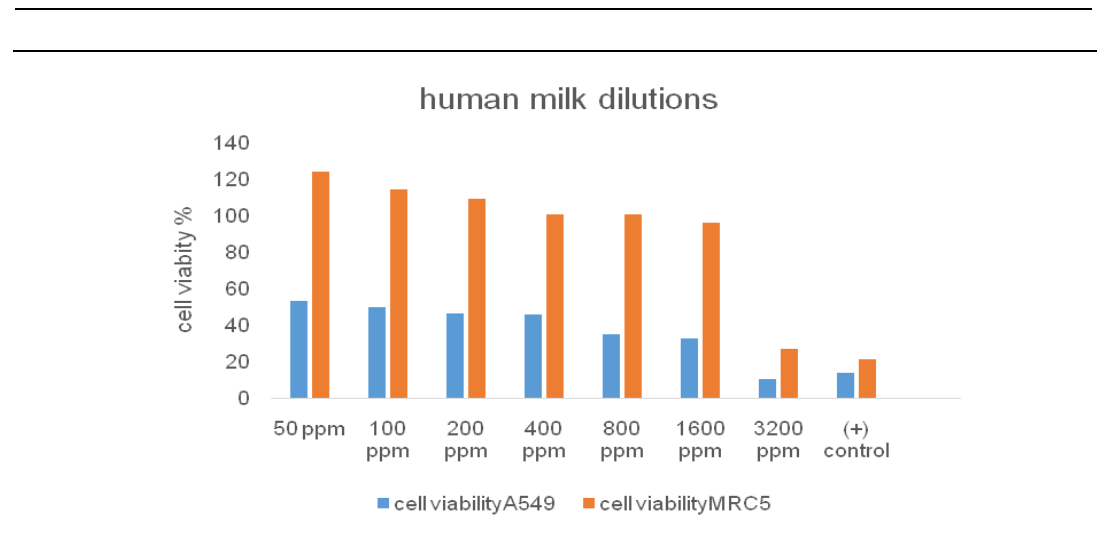

Figure 3. Effect of human milk on cell viability of A549 and MRC5 cell lines at different concentrations 


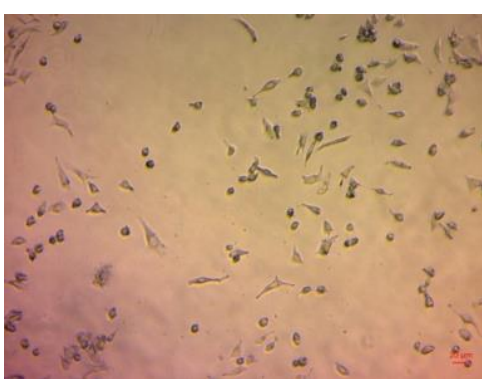

(a)

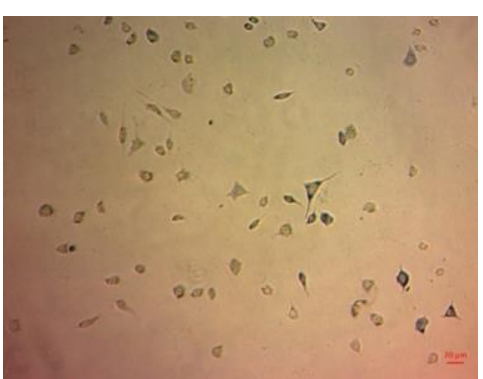

(b)

Figure 4. Optic images of mare milk exposed to cell lines; (a) A549 cancer cell line (3,200 ppm) and (b) MRC5 cell line (50 ppm); The images were collected at 10X magnification.

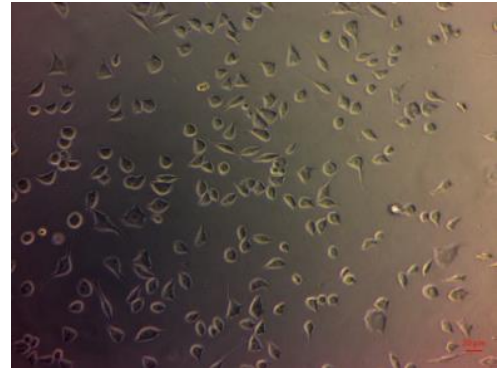

(a)

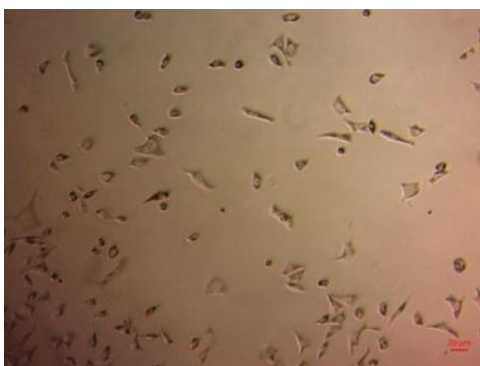

(b)

Figure 5. Optic images of mare milk and human milk exposed to cell lines; (a) Mare milk exposed to MRC 5 cancer cell line $(1,600 \mathrm{ppm})$ and (b) human milk A549 cell line $(1,600 \mathrm{ppm})$; The images were collected at 10X magnification

and Table1) applied to A549 cancer cells and MRC5 healthy cells at concentrations of $3,200 \mathrm{ppm}$ and 100 ppm, respectively.

The objective image in Figure 7a is a microscope picture of human milk (shown in Figure 3 and
Table1) applied to MRC5 healthy cells at a concentration of $200 \mathrm{ppm}$. The objective image in Figure $7 \mathrm{~b}$ is a microscope view of the interaction of A549 cancer cells with the medium as a negative control.

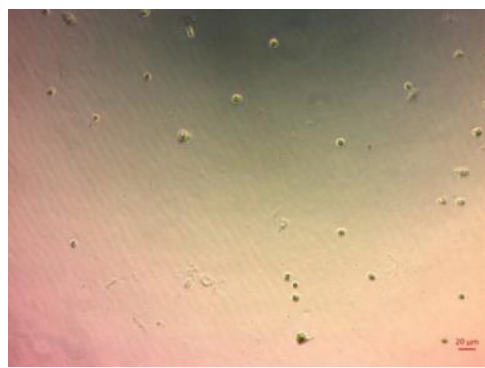

(a)

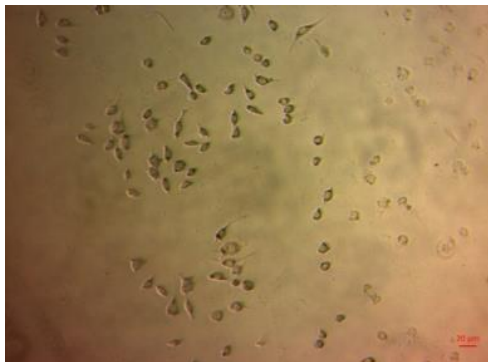

(b)

Figure 6. Optic images of human milk exposed to cell lines; (a) A549 cancer cell line (3,200 ppm) and (b) MRC5 cell line $(100 \mathrm{ppm})$; The images were collected at 10X magnification

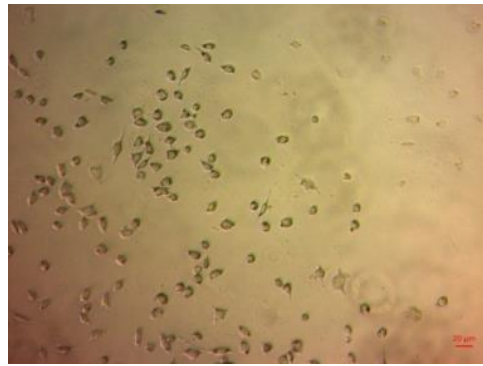

(a)

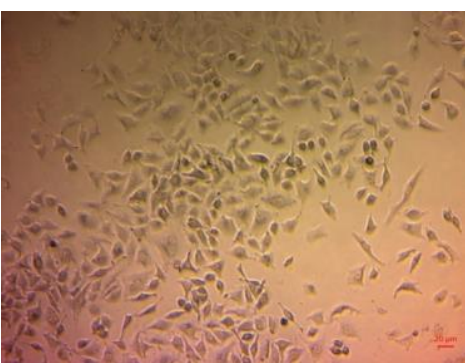

(b)

Figure 7. Optic images of human milk exposed to cell lines; (a) MRC5 cancer cell line (200 ppm) and (b) A549 cell line positive control; The images were collected at 10X magnification 


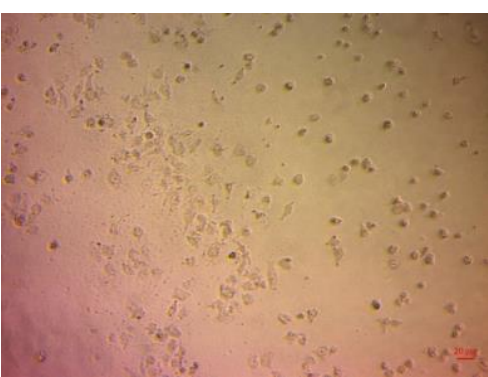

(a)

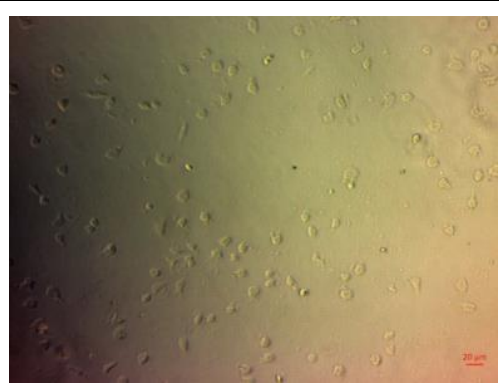

(b)

Figure 8. Optic images of positive control cell lines; (a) A549 cancer cell line and (b) MRC5 cell line; The images were collected at $10 \mathrm{X}$ magnification.

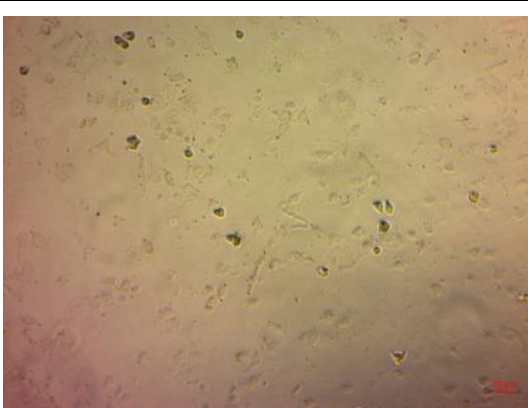

(a)

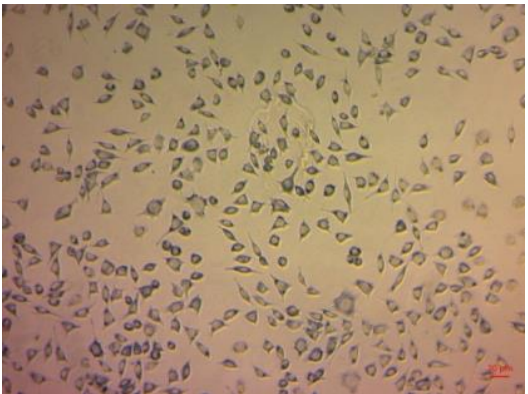

(b)

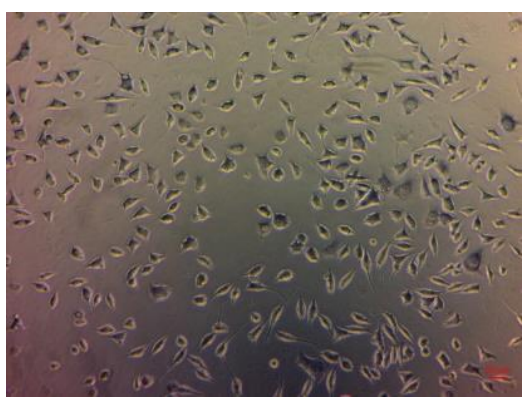

(c)

Figure 9. Optic images of cow colostrum exposed to cell lines; (a) A549 cancer cell line (3,200 ppm), (b) MRC5 cell line (50 ppm), and (c) MRC5 negative control; The images were collected at 10X magnification.

Figures $8 \mathrm{a}$ and $8 \mathrm{~b}$ are the microscope views of the interactions of A549 cancer cells and MRC5 healthy cells with $\mathrm{H}_{2} \mathrm{O}_{2}$ as positive controls, respectively.

The objective images in figures $9 \mathrm{a}$ and $9 \mathrm{~b}$ are the microscope pictures of cow's milk (shown in Figure 2 and Table 1) applied to A549 cancer cells and MRC5 healthy cells at concentrations of 3,200 ppm and 50 ppm, respectively. The picture in Figure $9 \mathrm{c}$ is a microscope image of the interaction of MRC5 healthy cells with the medium as a negative control.

\section{Discussion}

Milk products contain a large number of probiotic bacteria and metabolites. The release of this content during the fermentation of probiotic bacteria in dairy products may prevent colorectal carcinogenesis (23). Earlier reports showed that fermented milk products had many health-improving effects, such as the reduction of serum cholesterol, improvement of lactose metabolism, and reduction of cancer risk (24-26). Moreover, van't Veer et al. hypothesized that high consumption of fermented milk products (predominantly yogurt and buttermilk) may create protection against breast cancer (27).

The results of previous studies have shown the preventive effects of cow milk and its effect on breast and esophageal cancer in cell lines. However, in our study, lyophilized cow colostrum showed little effect on reducing lung cancer cells and improving the viability of healthy cells (Figure 2, Figure 9a, and Figure 9b). Duarte et al. (8) conducted a study on the anti-cancer properties of bovine milk lactoferrin on human breast cancer HS578T and T47D cells. The cancer cells were treated with lactoferrin concentrations ranging from $0.125-125 \mu \mathrm{M}$ and they showed that LF has great potential to be used in breast cancer treatment (8). Farziyan et al. reported that LF obtained from bovine colostrum showed an inhibitory effect on 


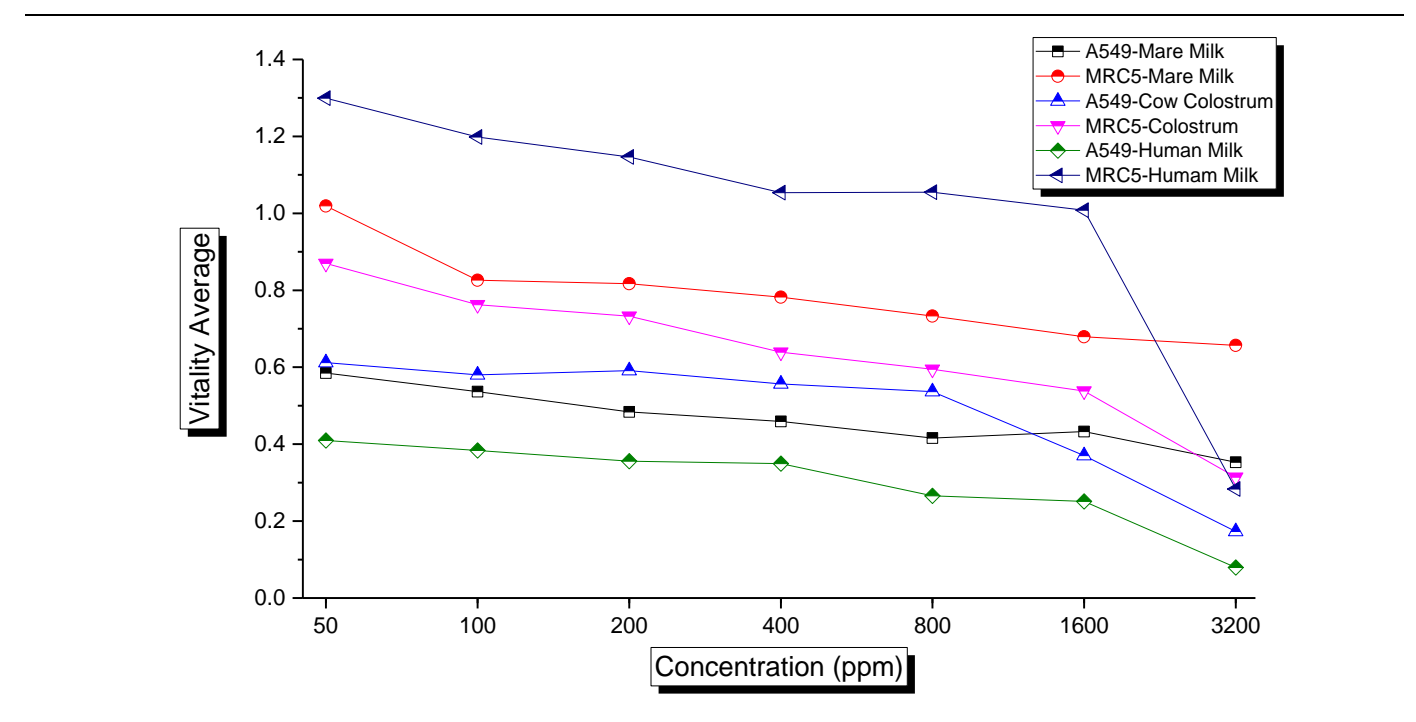

Figure 10. Concentration-dependent vitality average change graph of the effect of three milk groups on A549 and MRC5 cell lines.

esophageal cancer cell line KYSE-30, and the MTT assay test (28) indicated that $500 \mu \mathrm{g} / \mathrm{ml}$ of $\mathrm{LF}$ reduced cell viability in esophageal cancer cell lines KYSE by $53 \%$ and $80 \%$ after 20 and $62 \mathrm{~h}$, respectively (29).

Furthermore, in another report, the effect of donkey milk on A549 lung cancer and BEAS-2B healthy lung cell lines were investigated. Donkey milk showed lower cytotoxic effects against healthy lung cell lines in comparison to the tumor cell line. This data indicated that donkey milk had anti-proliferative effects on lung cancer cells at concentrations that were non-toxic to normal lung cells (9). In our study, mare milk showed a similar effect in the same cancer lines (Figure 1 and Figure 4).

Figure 10 shows the variations in human milk, cow colostrum, and mare milk in A 549 cancer and MRC 5 healthy cell lines. Lyophilized human milk has been applied to A549 cancer cell lines and MRC5 healthy cell lines. The effect of cell viability was mostly detected in human milk (Table 1, Figure $5 b$, Figure 6a, Figure 6b, and Figure 7a). A similar change was observed by lyophilized mare milk at slightly lower values (Table 1 and Figure 4). Lyophilized cow colostrum showed little effect on reducing lung cancer cells and improved the viability of healthy cells (Table 1, Figure 2, Figure $9 \mathrm{a}$, and Figure 9b). This change was found to be at its highest and lowest concentrations at 50 and 800 ppm, respectively. The most effective change in A549 cancer cell lines, compared to MRC5 healthy cell lines, was revealed to be in human milk (Figure 3 , Figure 5b, Figure 6a, Figure 6b, and Figure 7a). In this case, it was observed that lyophilized human milk reduced the density of A549 lung cancer cells in parallel with increasing concentration; nevertheless, it increased cell viability in MRC5 healthy lung cells.

\section{Conclusion}

This study investigated the anti-cancer properties of various mammalian milk in 7 different concentrations by using A549 lung cancer cell line and MRC5 healthy lung cell lines as in vitro studies. Based on the results of this research, human milk was the most effective type of milk in reducing the human lung cancer cell line called A549, followed by mare's milk, while cow colostrum had little effect. Human milk and mare's milk have been observed to have anti-proliferative effects on the lung cancer cell line at concentrations non-toxic to the healthy lung cell line. The researchers of the current study will focus on the employment of these milk samples in animal models in their prospective study.

\section{Acknowledgments}

The author would like to extend his deepest gratitude to Mehmet Yilmaz, Asli Yilmaz, and Ferhunde Aysin from Ataturk University (Erzurum, Turkey) for their contribution.

\section{Footnotes}

Conflicts of Interest: The author declare that there is no conflict of interest.

Ethical Approval: Ethical committee was not required for conduct this study in Turkey.

Funding/Support: The author declare that there is no funding.

Financial Disclosure: The author declare that there is no financial disclosure.

Informed Consent: Informed consent was not required to conduct this study in Turkey. 


\section{References}

1. Sun Y, Zhu S, Ma K, Liu W, Yue Y, Hu G, et al. Identification of 12 cancer types through genome deep learning. Sci Rep. 2019; 9(1):17256. doi: 10.1038/s41598-019-53989-3. [PubMed: 31754222].

2. Torre LA, Bray F, Siegel RL, Ferlay J, Lortet-Tieulent J, Jemal A. Global cancer statistics, 2012. CA Cancer J Clin. 2015;65(2):87108. doi: 10.3322/caac.21262. [PubMed: 25651787].

3. Siegel RL, Miller KD, Jemal A. Cancer statistics, 2019. CA Cancer J Clin. 2019;69(1):7-34. doi: 10.3322/caac.21551. [PubMed: 30620402].

4. Bray F, Ferlay J, Soerjomataram I, Siegel RL, Torre LA, Jemal A. Global cancer statistics 2018: GLOBOCAN estimates of incidence and mortality worldwide for 36 cancers in 185 countries. CA Cancer J Clin. 2018;68(6):394-424. doi: 10.3322/caac.21492. [PubMed: 30207593].

5. Tagliazucchi D, Shamsia S, Helal A, Conte A. Angiotensinconverting enzyme inhibitory peptides from goats' milk released by in vitro gastro-intestinal digestion. Int Dairy J. 2017;71:6-16. doi: 10.1016/j.idairyj.2017.03.001.

6. Rafiq S, Huma N, Rakariyatham K, Hussain I, Gulzar N, Hayat I. Anti-inflammatory and anticancer activities of water-soluble peptide extracts of buffalo and cow milk Cheddar cheeses. Int J Dairy Technol. 2018;71(2):432-8. doi: 10.1111/14710307.12483

7. Kim H, Ahn SI, Jhoo JW, Kim GY. Comparison of allergic parameters between whey protein concentrate and its hydrolysate in rat basophilic leukemia (RBL)-2H3 cells. Korean J Food Sci Anim Resour. 2018;38(4):780-93. doi: 10.5851/kosfa.2018.e16. [PubMed: 30206437].

8. Duarte DC, Nicolau A, Teixeira JA, Rodrigues LR. The effect of bovine milk lactoferrin on human breast cancer cell lines. $J$ Dairy Sci. 2011;94(1):66-76. doi: 10.3168/jds.2010-3629. [PubMed: 21183018].

9. Akca C, Vatan O, Yilmaz D, Huriyet H, Cinkilic N, Cavas T. In vitro cytotoxic and genotoxic effects of donkey milk on lung cancer and normal cells lines. Czech J Food Sci. 2019;37(1):2935. doi: 10.17221/221/2018-CJFS.

10. Gura T. Nature's first functional food. Science. 2014; 345(6198):747-9. doi: 10.1126/science.345.6198.747. [PubMed: 25124424].

11. Løland BF, Baerug AB, Nylander G. Human milk, immune responses and health effects. Tidsskr Nor Laegeforen. 2007;127(18):2395-8. [PubMed: 17895946].

12. Savino F, Benetti S, Liguori SA, Sorrenti M, Cordero Di Montezemolo L. Advances on human milk hormones and protection against obesity. Cell Mol Biol (Noisy-le-grand). 2013;59(1):89-98. [PubMed: 24200024].

13. do Carmo França-Botelho A, Ferreira MC, França JL, França EL, Honório-França AC. Breastfeeding and its relationship with reduction of breast cancer: a review. Asian Pac J Cancer Prev. 2012;13(11):5327-32. [PubMed: 23317179].

14. Uruakpa FO, Ismond MA, Akobundu EN. Colostrum and its benefits: a review. Nutr Res. 2002;22(6):755-67. doi: 10.1016/S0271-5317(02)00373-1.

15. Wheeler TT, Hodgkinson AJ, Prosser CG, Davis SR. Immune components of colostrum and milk--a historical perspective. J Mammary Gland Biol Neoplasia. 2007;12(4):237-47. doi: 10.1007/s10911-007-9051-7. [PubMed: 17992474].
16. Wang S, Tu J, Zhou C, Li J, Huang L, Tao L, et al. The effect of Lfcin-B on non-small cell lung cancer H460 cells is mediated by inhibiting VEGF expression and inducing apoptosis. Arch Pharm Res. 2015;38(2):261-71. doi: 10.1007/s12272-0140373-x. [PubMed: 24691828].

17. Montanari G, Zambonelli C, Grazia L, Kamesheva GK, Shigaeva MK. Saccharomyces unisporus as the principal alcoholic fermentation microorganism of traditional koumiss. I Dairy Res. 1996;63(2):327-31. doi: 10.1017/S0022029900031836.

18. Watanabe K, Fujimoto J, Sasamoto M, Dugersuren J, Tumursuh T, Demberel S. Diversity of lactic acid bacteria and yeasts in Airag and Tarag, traditional fermented milk products of Mongolia. World J Microbiol Biotechnol. 2008;24(8):1313-25. doi: $10.1007 / \mathrm{s} 11274-007-9604-3$.

19. Uniacke-Lowe T, Huppertz T, Fox PF. Equine milk proteins: chemistry, structure and nutritional significance. Int Dairy J. 2010;20(9):609-29. doi: 10.1016/j.idairyj.2010.02.007.

20. Yao G, Yu J, Hou Q, Hui W, Liu W, Kwok LY, et al. A Perspective study of koumiss microbiome by metagenomics analysis based on single-cell amplification technique. Front Microbiol. 2017;8:165. doi: 10.3389/fmicb.2017.00165. [PubMed: 28223973].

21. Zhang W, Sun Z, Sun T, Zhang H. PCR screening and sequence analysis of iol clusters in Lactobacillus casei strains isolated from koumiss. Folia Microbiol (Praha). 2010;55(6):603-6. doi: 10.1007/s12223-010-0097-3. [PubMed: 21253906].

22. Pan DD, Zeng XQ Yan YT. Characterisation of Lactobacillus fermentum SM-7 isolated from koumiss, a potential probiotic bacterium with cholesterol-lowering effects. J Sci Food Agric. 2011;91(3):512-8. doi: 10.1002/jsfa.4214. [PubMed: 21218486].

23. Ebringer L, Ferencík M, Krajcovic J. Beneficial health effects of milk and fermented dairy products--review. Folia Microbiol (Praha). 2008;53(5):378-94. doi: 10.1007/s12223-008-00591. [PubMed: 19085072].

24. Parvez S, Malik KA, Ah Kang S, Kim HY. Probiotics and their fermented food products are beneficial for health. Appl Microbiol. 2006;100(6):1171-85. doi: 10.1111/j.13652672.2006.02963.x. [PubMed: 16696665].

25. Vasiljevic T, Shah NP. Probiotics-from Metchnikoff to bioactives Int Dairy J. 2008;18(7):714-28. doi: 10.1016/j.idairyj.2008. 03.004 .

26. Desrouillères $K$, Millette $M$, Jamshidian $M$, Maherani $B$, Fortin 0 , Lacroix M. Cancer preventive effect of a specific probiotic fermented milk components and cell walls extracted from a biomass containing L. acidophilus CL1285, L. casei LBC80R, and L. rhamnosus CLR2 on male F344 rats treated with 1,2 dimethylhydrazine. J Functional Foods. 2016;26:373-84. doi: 10.1016/j.jff.2016.08.005.

27. van't Veer P, Dekker JM, Lamers JW, Kok FJ, Schouten EG, Brants HA, et al. Consumption of fermented milk products and breast cancer: a case-control study in The Netherlands. Cancer Res. 1989;49(14):4020-3. [PubMed: 2736542].

28. Maehara Y, Anai H, Tamada R, Sugimachi K. The ATP assay is more sensitive than the succinate dehydrogenase inhibition test for predicting cell viability. Eur I Cancer Clin Oncol. 1987; 23(3):273-6. doi: 10.1016/0277-5379(87)90070-8. [PubMed: 3109921].

29. Farziyan MA, Moradian F, Rafiei AR. Anticancer effect of bovine lactoferrin on human esophagus cancer cell line. Res Mol Med. 2016;4(1):18-23. doi: 10.7508/rmm.2016.01.003. 